\title{
Liminality in J.M. Coetzee's later experimental texts
}

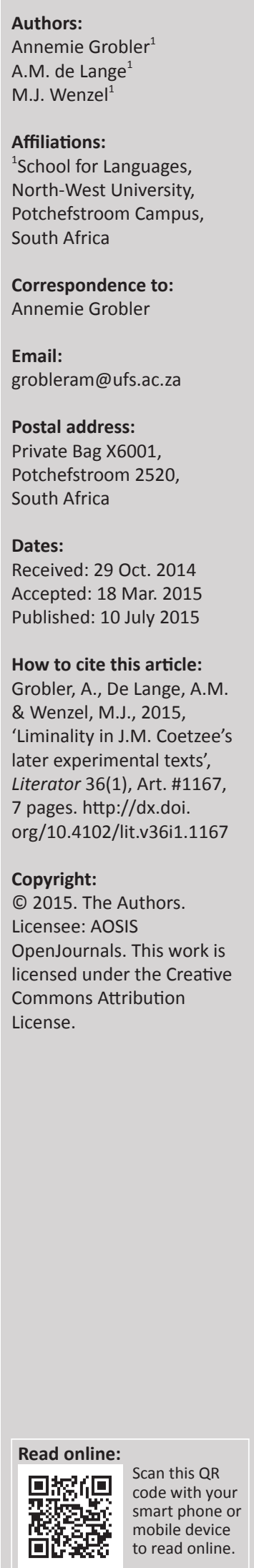

Postcoloniality, which is essentially concerned with the transition and transgression of boundaries and borders, contextualises and defines liminality as an ephemeral concept that eludes pinning down. Liminality is continually involved in a dual process of evolving and subverting: dynamic in the sense of promoting the centre, but subversive in its destabilisation of the previous status quo. In the more recent novels by Coetzee (Slow man, Diary of a bad year, Elizabeth Costello), themes that are especially acute in highlighting the subversive nature of liminality emerge repeatedly: the threshold, death, proliferation and imitation. The problem investigated is: how is the concept of liminality developed in these novels? An examination of these novels in terms of the above-mentioned themes and various conceptual and theoretical elements shows that Coetzee encourages the reader to assume a liminal status, not only as reader of the texts but also in relation to contemporary reality. It is concluded that Coetzee uses certain themes that promote liminality, often in a subversive and deconstructive manner, to inform the reader and, thus, influence him or her to effect change in the contemporary world.

Liminaliteit in J.M. Coetzee se latere eksperimentele tekste. Liminaliteit word as 'n efemere en ontwykende konsep gekontekstualiseer deur postkolonialisme, wat in wese te make het met die oorsteek en oorgang van grense. Liminaliteit is voortdurend betrokke in 'n tweeledige proses van ontwikkeling en ondermyning: dinamies in die sin van die bevordering van die sentrum, maar ondermynend in die destabilisering van die vorige status quo. In Coetzee se meer onlangse romans (Slow man, Diary of a bad year, Elizabeth Costello), verskyn temas wat die subversiewe aard van liminaliteit skerp kan uitwys, voortdurend: die drumpel, die dood, vermeerdering en nabootsing. Die probleem wat ondersoek is, is: hoe word die konsep van liminaliteit in hierdie romans ontwikkel? $\mathrm{Na}$ 'n ondersoek van bogenoemde romans in terme van die voorgenoemde temas, is bevind dat Coetzee die leser aanmoedig om ' $n$ liminale status aan te neem nie alleen as leser van die teks nie, maar ook in die leser se eietydse werklikheid. Die gevolgtrekking is dat Coetzee bepaalde temas gebruik om liminaliteit te bevorder, dikwels op 'n subversiewe en dekonstruktiewe wyse, om die leser in te lig, maar ook om hom of haar aan te moedig om self verandering in sy of haar eietydse wêreld te bewerkstellig.

\section{The problem investigated}

Postcolonial literature promotes a new and diverse identity that is characterised by hybridity (Helgesson 2004:42). Hybridity is a result of the infiltration and cross-fertilisation that is caused by transgressing borders, whether social or textual, and as such is associated with liminality. Liminality, effected by the changes allowed by the postcolonial context, necessarily invokes instability and insecurity as its very nature defies the authority of borders and boundaries (Aguirre 2006:16). The consequence of this defiance is to open up possibilities for the fictional characters inhabiting these spaces to develop, expand and investigate, as the characters are confronted with the incertitude of the unknown, unrecognised, and the unclaimed.

The existence of borders already implies a twofold ambiguity: they are not only inclusive but also exclusive. Arndt (2006:39) notes that the presence of a border implies its susceptibility for being crossed and violated. In fact, liminality itself is essentially subversive: any border or boundary prompts its crossing, which in turn develops a new border in an infinitely repetitive mode (Aguirre 2006:17; Manzanas Calvo 2006:89). Liminality, therefore, is incessant, re-creative, and dynamic. When applying this notion to history it is likely that present political or social priorities colour the past. From this point of view, the past is continuously subverted or readjusted by the present in the incessant play of temporal liminality.

This article examines how and to what extent Coetzee attempts to introduce liminality, as a concept, to the reader of his fiction. 


\section{Method of investigation}

The question stated above is investigated heuristically and empirically through the lens of a conceptual-theoretical framework which identifies concepts typically associated with postcolonial literature. The most significant of these are liminality and the development of subversion through both a variety of techniques (phasing, aporia, alternatives) and subversive themes (the threshold, death and copy or imitation) which have been identified in Coetzee's most recent texts. Theoretical sources consulted, regarding these techniques, include works by Fahraeus and Jonsson (2005), Aguirre (2006), Manzanas Calvo (2006) and Palmer (2004), as well as Du Plooy's excellent marshalling of the concept of liminality (2006).

The emphasis shifts from a theoretical point of departure, to the application of these theoretical and conceptual concepts in Coetzee's literary texts, before the findings, in this regard, are listed and discussed and a general conclusion regarding the subversive nature of liminality is formulated.

\section{Conceptual and theoretical framework}

The following conceptual and theoretical elements will be used in this essay:

- subverting the past

- aporia

- phasing

- repetition

- allegorical structure

- synecdoche

- the threshold

- death

- copy and original.

A brief discussion of each one of these follows.

\section{Subverting the past}

Worthington (1996:15) comments that writing cannot directly correspond with the past as it really was, but rather mediates and modulates the events of the past from a present interpretative moment. Palmer (2004:110) claims that the broad consensus amongst writers seems to be that memory is a container of possibilities in which the past is seen as actively causing or generating the present and the future. Searle (1992:187) defines memory 'as a mechanism for generating current performance', such as 'conscious thoughts and actions, based on past experience'. All these critics regard the past as actively causing or generating the present and the future.

This approach to reading is reminiscent of the Y-structure suggested by Gallagher (2002:11-31) which she primarily applies to texts that deal with time travel but which could equally well apply to the notion of an alternative history.
She argues that an alternative history, which she calls counterfactuality, exists and illustrates it with examples of time-travelling movies - where a person goes back in time in order to change the course of history in such a way that the present never happens. Instead of the commonly accepted time scheme of circular loops, she suggests a Y-scheme, in which the time traveller goes back to the point just before the events split off in different directions. She calls such a plot 'undoing', noting that it might provide a plot type needed to identify past events whose alteration or undoing would lead to a substantially different present. She links this device to 'our collective ambitions to undo certain events in our national past' (Gallagher 2002:13). These attempts are closely associated with the consequences of past discrimination based on race and gender. She explains that people are fascinated by the notion of regarding the future from the perspective of a different past. She mentions the example of Isaac Disraeli, who published a 'History of events that never happened' in the early 19th century. This example illustrates the human desire for imagining an alternative to reality that may be more acceptable to our minds. Cattin's (1999:15) phrase is memorable: 'allowing for the possibility of a different scene is precisely what makes us human'. These critics are cited as they are pertinent to the theoretical conclusions drawn in this article.

In the fluid and adaptable context created by liminality, Aguirre (2006:93) argues that a middle ground is constructed where the past, although unchanged, is now assessed differently. The wisdom of hindsight combines with memory and perception to create a new version of history - in which it is even possible to supplant existing history with a new version. Following this argument it is easy to comprehend that copy can replace original in the same way that representation can replace presentation (which is already a rendering, version or imitation of the historic facts). In this regard one is reminded of Fahraeus's and Jonsson (2005:1) remark that the growing interest in forms of repression and usurpation bears witness to the current concern with textual ethics in a postcolonial context.

\section{Technique: Aporia}

Derrida ([1976] 1986) uses the term aporia to refer to the point in a text which forecloses a certain outcome, a certain interpretation of the text. As such it suggests the possibility of various interpretations. In this context, Fahraeus and Jonsson (2005:7) agrees with Derrida's view of aporia as a narrative technique that conveys authorial involvement.

\section{Technique: Phasing}

The technique of phasing occurs in its simplest form when the plot is interrupted or segmented into different parts. It is common in children's stories, medieval narratives and folk tales where, for example, three sons each set off to conquer the world, each one meeting with failure until the third, youngest or elected one manages to fulfil the requirements that had been set up as prerequisites for success. It also 
echoes the kaleidoscopic image as different perspectives on the same plot are supplied in various versions.

Aguirre (2006) offers the following definition of phasing:

Phasing has a prismatic function which diffracts events into a number of significant moments or unfolds them into a sequence of episodes. In breaking down motion into several stages, phasing achieves duration, suspense, and solemnity; suggesting order, closure, disclosure, completion, finality and inevitability. It is a favourite strategy of all folk narratives, medieval storytellers and equally at work in gothic fiction. (p. 19)

According to Aguirre (2006:19), the obvious result of this technique is to retard the narrative. Related techniques include the device of the fragmented manuscript (which is illegible in places), interrupted narrative, labyrinthine spaces and withheld or insufficient information.

Aguirre (2006:20-21) notes that, from one perspective, phasing builds up a view of the cosmos which includes time itself; in another way, it defamiliarises reality, resulting in the same function performing both ways. With regard to the construction of a plot, Aguirre argues that retardation primarily affects the characters as it shapes their world and does not in the first place affect the reader's perception of reality. Therefore, this technique is viewed according to its effect on characters.

\section{Technique: Repetition}

Manzanas Calvo (2006:101) echoes Gallagher (2002:11) in noting that the convergence of the past with the present does not alter the past but alters the evaluation of it; it opens a new intermediary space beyond the real and beyond realism. Repetition, such as that produced by representing both copy and original or various versions of either, constitutes a convergence in the here and now, more than it offers an escape from the present. To me, this points to reader involvement, as these multiple layers cannot intertwine without the reader's active participation. Therefore, unlike phasing, which is associated with characterisation, the strategy of repetition can be classified as being concerned with the readers' assessment of its impact.

\section{Technique: Allegorical structure}

According to Dovey (1988:387), postcolonial allegory must of necessity be regarded as a palimpsest. Dovey (1988:394) notes that allegorical imagery in postmodernism merely simulates and appropriates but never creates original elements.

Samuelson (2006:184) observes that the allegorical structure of South African novels, published during the transition period from apartheid to rainbow nation, characteristically prefer a focus on race rather than on gender in a rhetoric of elision in which the past continues to exert control over the present. Dovey (1988:51) points out that allegory seems to surface regularly in critical or polemical atmospheres when, for political or metaphysical reasons, there is something that cannot be said in a transparent way.

\section{Technique: Synecdoche}

Synecdoche, according to the Oxford English dictionary (2007:769), is a figure of speech in which a part represents the whole or vice versa. According to Boehmer (2005:190, 1998:523), synecdoche provides the connective tissue of early postcolonial writing. The Bloomsbury guide to English Literature comments that synecdoche is essentially associated with realistic representation as it combines attributes of similar objects. The function of synecdoche is to build up tension according to Aguirre (2006:3), mentioning it in conjunction with the representation of the Other, as a site that variously expands, absorbs or colonises.

\section{Theme: The threshold}

The threshold can be described as a waiting area that suggests a time and space in transit, an inter-medium where memory does not accumulate and which has no established paths (Manzanas Calvo 2006:92). This space is capable of creating a sense of insecurity through the absence of a past. In this sense the liminal waiting space is associated with the technique of secrecy, as it resembles a bottomless hole into which time and memory would spiral into indeterminacy. Liminal space, as a waiting area, is associated with purgatory and its connotations of penitence and purification. This indicates its relevance and similarity to the themes of death and copy or original, emphasising the complex proximity of these ideas.

\section{Theme: Death}

Death as the conclusion of all existence seems to be final and irrevocable. But is it final? The suspicion persists that death must be regarded as reaching the boundary of one plane of existence before embarking on the crossing of the frontiers to a next level of being. It seems logical to argue that death is part of a system of renewal and as such not merely symbolic of a new beginning. Instead it is a progression to a new level of being that incorporates the wisdom of experience that was gained previously. Growth cannot be accomplished without reaching and transgressing the borders in the same way that death introduces the new beginning in an infinite cycle. Death can, therefore, be regarded as liminal but also subversive, as the act of dying does not settle the matter but is the essential, preliminary step toward renewal, albeit in a changed form.

\section{Theme: Copy and original}

The relationship between the original and the copy is complex. The status of the original is both affirmed and threatened by the creation of a copy - similar to the identity of the border that is both claimed and contested from the inside as much as the outside. Also, the copy is just as much a reflection of the original as it is an impostor. The tension between original and copy encourages liminality as it threatens the status of the original but also simultaneously precludes the memory of the original from being erased. 


\section{Coetzee's application of insights, themes and techniques discussed in the conceptual-theoretical framework}

\section{An alternative past}

The possibility of an alternative history features almost routinely in Slow man. Rayment's fervent desire to go back to his previous life, the one before the accident on Magill Road, is referred to often (Coetzee 2006:122): 'There is a second world that exists side by side with the first, unsuspected ...' Also, Rayment muses that Costello is capable of fabricating a second world as she is composing two concurrent stories:

Or might the Costello woman be writing two stories at once, stories about characters who suffer a loss (sight in the one case, ambulation in the other) which they must learn to live with; and, as an experiment or even a kind of professional joke, might she have arranged for their two life-lines to intersect? (Coetzee 2006:118)

The possibility that the incident on Magill Road could have turned out differently is indicated as an aporia and emphasised by repeated reference to it, not only by Rayment (Coetzee 2006:1,19) but also by Costello (Coetzee 2006:81, 83). Rayment himself points at the possibility of Marijana consenting to his overtures instead of staying loyal to Miroslav: 'If we had had but five minutes more ...' (Coetzee 2006:235).

Slow man contains many examples of phasing episodes, most of them as flashbacks to Rayment's childhood. He recalls his mother in France, reading idle love stories and playing the piano (Coetzee 2006:52). Rayment recalls reading a popular legend by Plato (Coetzee 2006:53) in what seems to cast Rayment himself in a caricature of the gods.

Drago is compared to Narcissus in a phasing episode (Coetzee 2006:163) and Miroslav's expertise in a different world, in his country of origin, is explained (Coetzee 2006:91) in another phasing incident. Diary of a bad year also employs a phasing structure but in this case it is structural in the delivery of the text: the three sections variously present different points of view, ranging from JC's private and personal persona, to Anya's points of view in relation to JC and to Alan, and to Alan's opinions on a variety of topics.

To consider the notion of allegory, it is possible to interpret Rayment's loss of his leg and his mobility as allegorical of the loss of his foundation, he being an immigrant in Australia (which could also reflect on the fact that Coetzee himself forswore his home country [South Africa] when he emigrated to Australia).

The threshold is a theme that often bears discussion in Slow man. Rayment is aware that Costello expects him to progress beyond a certain threshold in his relationship towards Marianna (Coetzee 2006:116), the person introduced and offered by Costello as substitute to the unavailable Marijana. Costello speaks of Marijana Jokić as [not] being 'on the stage'
(Coetzee 2006:140), inferring that she is not a character to be pushed around at whim by a director, but a person with her own separate life and intentions. Being watched creates a certain discomfort in Rayment, as he perceives, with Marianna, that he is expected to play a part that has been scripted for him - obviously ruling out the possibility of freedom to act in ways beyond what was imagined. Rayment is intensely aware of a threshold that he and Marianna need to cross. In terms of their relationship it means overcoming the barrier of their handicaps-he with struggling to adapt to the inflicted blindness and she with having to compensate for his unbalanced body. Referring to Costello, he explains to Marianna:

She is of the opinion that until I have crossed a certain threshold I am caught in limbo, unable to grow. That is the hypothesis she is testing out in my case. She probably has another hypothesis to cover you. (Coetzee 2006:112)

The threshold is regarded as a ludicrous image by the projected, imagined figure of Marianna-Natasha (at an existential threshold herself), who, in his mind, ridicules Rayment for his seriousness (Coetzee 2006:116). Likewise, Rayment's dignity is dealt a heavy blow by Ljuba, who refers to him not as 'Rocket Man', the way he would honour himself, but as 'Slow Man', as he is depicted as a figure of ridicule on the brink of the threshold (Coetzee 2006:256). 'Caught in limbo' is an apt description of what happened to Rayment during the accident on Magill Road: 'Relax! He tells himself as he flies through the air (flies through the air with the greatest of ease!), and indeed he can feel his limbs go obediently slack' (Coetzee 2006:1). Rayment's apparently matter-of-fact mention of the words limber, limbre or limbo (Coetzee 2006:112) is not unintentional, as they conjure up associations of suspension, thus, adding depth of meaning to the juxtaposed innuendos, and also emphasising the elasticity of the threshold as liminal space.

The concept of purgatory is introduced in Elizabeth Costello as part of a tertiary system that dismantles the binary oppositions: inferior and superior, powerless and powerful, rich and poor of the colonialist system ${ }^{1}$ to be replaced by a more complex triad, which corresponds to the idea of liminality.

\section{Theme: Death}

Death is a recurrent theme throughout Coetzee's oeuvre. In Diary of a bad year JC often refers to his own failing health and awareness of his mortality: 'That is part of my condition. That is part of what is happening to me' (Coetzee 2007:31). He even has a nightmarish dream in which it seems that Anya, as an angel or escort, is designated to guide him 'to the gateway of oblivion' (Coetzee 2007:59). The strong opinion, entitled On the body, discusses animal suffering and dying in the top section, presents JC's dream about his death in the middle section, and in the bottom section concerns Anya's

1.Talib (2002:3) discusses the identity of English as a language in a postcolonialist phase, remarking that the English have come to regard themselves and their phase, remarking that the English have come to regard themselves and their
language as necessarily bearing the evidence of both having been colonised but also potentially colonising others. 
argument with Alan, who wants to sue JC (which can be equated with a sophisticated, civilised execution) for having licentious thoughts about her (Coetzee 2007:59-61). Finally, when it seems inevitable that JC is dying, Anya acquiesces to become what has been referred to earlier, the unlikely angel ushering JC on his journey to the beyond.

It is interesting to note that the novel ends with Anya wishing JC farewell on his journey to the next life, which suggests the death of the fictional character JC. Whilst this could have been a symbolic way to announce the end of Coetzee's publications, this question has already been answered by the publication of his latest novel, The childhood of Jesus (2013), which text finally disassociates him from the fictional writer, narrator and character JC Coetzee has never failed to surprise his audience by reinventing himself and will probably do so again.

\section{Theme: Copy and original, repetition and imitation}

Repetition does not imply escaping the present, but rather indicates a convergence of everything in the here and now. It is at this point that Coetzee involves the reader in establishing significance in the text. Similar to the process in Foe, as Manzanas Calvo (2006:101) remarks, the dialectics between copy and original become confused when it becomes unclear which is which in Elizabeth Costello.

This convergence described above does not change the past, but can alter its assessment, as noted by Manzanas Calvo (2006:101) and also by Aguirre (2006:21) $)^{2}$. Manzanas Calvo (2006:101) mentions that it opens a new intermediary space beyond the gate of the real and beyond the expressive means of realism where the displaced or removed past may have a major, although intermittent presence. The lack of temporal and spatial frontiers is evident in narrative terms as well, for there is no narrative closure with which to edify the reader.

The many variations of parts of Foe also add to the idea of copy and original. The scene between Friday and Barton which is echoed by the unnamed couple lying face to face suggests this mirror effect, as does the appearance of Barton's long-lost daughter who suddenly appears from Bahia, much to her mother's dismay.

\section{Interpretation}

Aguirre (2006:93) argues that Coetzee seems to formulate a new version of existence where the borders between self and others are excluded.

Coetzee is adept at using allegory as a metafictional vehicle for his texts and applies it as a vehicle of textual layering that adds to the richness of his novels, as remarked by Head (1997:7). The inherent danger in allegory is that the reader may be lured into falsely interpreting it as an absolute and

\footnotetext{
2.'If we examine the construction of the plot not with regard to ourselves as readers

exclusive reading. Dovey (1988:394) regards Coetzee's novels as 'allegories of irony', bearing in mind that allegorical imagery in postmodernism merely simulates and appropriates but never creates original elements. Manzanas Calvo (2006:101) notes that when copy and original become totally entwined, confounding any attempt to distinguish between them, it affirms the idea that Coetzee's fiction simulates allegory without equating itself to traditional allegory.

Secrecy and various associated rhetorical devices seem capable of extending in various directions as recurrent themes and motifs in Coetzee's work. According to Birks (2007:13-16), research in psychopathology gives reasons why certain things cannot be confronted, for example: the rape in Disgrace. As previously pointed out, allegory seems to surface regularly in critical or polemical contexts, when, usually for controversial reasons, there is something that cannot be explicitly stated (Dovey 1988:51). This fact is relevant to Coetzee's use of allegory when writing in the South African context and may also be applied to his strategies of concealment. Ultimately, the representation of handicap and physical molestation allows Coetzee to reflect on the actual nature and position of South African subjects in their complex relation to history and society. And yet the violence itself can be a true reflection of socio-political reality. The blurring of allegory and reality creates a complex reading experience, a figuring of 'copy and original' bordering on unheimlichkeit, thereby adding to the traumatic quality of the events portrayed. According to Birks (2007:16), the healing of trauma can be expedited by imaginative confrontation through the reading experience. Yet Coetzee leaves it to the reader to confront whatever issues his texts may raise; he is not didactic or prescriptive.

Critics disagree about the presence or not of allegory in Coetzee's texts. In a critique on Attridge's appraisal of Coetzee, May (2007:632-637) warns against Attridge's attempts to allegorise all or any part of Coetzee's works. In the final instance, however, it is probably impossible to avoid recognising elements of allegory in any reading of Coetzee.

Synecdochal instances allow us to see Lurie, the male focaliser in Disgrace, as representative of a predatory yet intelligent type of academic male. The loss of Rayment's leg in Slow man is even more properly synecdochal, as opposed to merely representative, (as already indicated above) as figuring the loss of a part of the self when one leaves the motherland - an image which also reflects on the author's situation.

Phasing can be seen in Coetzee's Diary of a bad year, where the narrative is segmented into three concurrent sections, simultaneously offering perspectives by JC and Anya, along with the superscribed comments of Señor C and JC on Anya's interferences. It is also evident in Elizabeth Costello, where the action is divided into eight 'lessons', indicative of a progression towards the climactic culmination of reaching 'the gates' (Coetzee 2003:193). The same idea is present in Foe, where Susan Barton presents not one but various versions of the same history, creating a textured and multi-layered whole 
in which original and copy merge, blurring the differences and confusing judgement (Coetzee 1986:113, 153). This technique functions repeatedly in Slow man (Coetzee 2006:81, $115,122)$.

Samuelson (2006:186) explains the diptych structure as setting up a partial mirror between two sets of relations. This structure can be indicated in Foe, for example, in the scenes of discovery between Susan Barton and the unnamed narrator, but also in the description of Barton meeting and coming face to face with her own daughter (Coetzee 1986:73-75). Using this structure Coetzee creates texture and repetition in the novel, similar to the repetitive instances in Slow man (Coetzee 2006:81, 115, 122) where Rayment desires for a different outcome to the fateful incident on Magill Road - but also in other instances. These instances illustrate Coetzee's application of the technique of aporia, suggesting the possibility of a different outcome, but combined with the confusion of repetition that is brought about by a blurring of copy and original.

A variation of phasing is repetition. The re-writing (or repeating) of Daniel Defoe's Robinson Crusoe provides the familiar site of numerous repetitions which allows Foe to become a literary palimpsest, superimposed upon an already jumbled layering of images. Dovey (1988:332) rightly remarks that the result of this multi-layering is that it becomes impossible to distinguish between what was original and what was superimposed. Manzanas Calvo (2006:101) adds that copy and original intertwine causing one to resemble the other, blurring the distinctions and, therefore, perpetuating the image.

Coetzee uses this technique regarding Susan Barton and her relationships with the Captain, with Cruso, with Foe and with Friday, to develop an intricate debate set amidst the discourses of feminism, postcolonialism and postmodernism, resulting in what Dovey (1988:334) calls 'an almost too-fertile ground for criticism': a debate that infinitely echoes the repetitive and innovative notions of liminality.

Ogden (2010:475-477) argues in favour of my claim that the textual construction of Diary of a bad year, together with Elizabeth Costello, constitutes an experiment in liminality, one that interrogates the traditional boundaries between fiction and 'knowledge'. Costello, as a liminal character, stands not as acclaimed writer but unknown and unremembered, alien to a common heritage or burden of remembering (Manzanas Calvo 2006:92). In my opinion this signifies that no growth or development is possible for Costello. This is important as it leaves the reader with the burden of passing judgement.

Costello insists that she only writes down, without passing judgement, similar to a secretary:

It is not for me to interrogate, to judge what is given to me. I merely write down the words and then test them, test their soundness, to make sure that I have heard right. (Coetzee 2003:199)
It is significant to note that this is in sharp contrast to what Coetzee expects of his readers - they are forced to judge, to participate! In Diary of a bad year Anya is also alluded to as a 'segretaria', adding a little Filipina flavour; which is possibly also an allusion to 'segregation'. Coetzee's ironic intent is very clear as Anya's lack of interpretative skills and basic knowledge precludes her from recording JC's opinions and arguments without mediation. To be fair, she makes her own interpretations and draws her own conclusions, showing an enterprising spirit that does not solicit patronisation.

Anya and Costello illustrate different positions and, therefore, may be regarded as one another's foil. Costello acts as a medium, as indicated by Graham (2006:225), but ironically denies herself the authority to intervene; Anya by contrast is supposed only to write down whilst she actively attempts to interpret.

In confessing before her jurors, Costello does not establish a beginning or end, but rather a middle ground where all voices are legitimate in their own right. This seems to create a new version of existence where the borders between the self and the other have been dismantled. Manzanas Calvo (2006:93) remarks that it is interesting that self-fashioning is similar and simultaneous to self-unfashioning. It is a space full of intellectual possibilities, inviting moral hybridity and moral possibility. The point here is that identity is not established without allusion to what is excluded. Just as identity cannot be defined only by the self without reference to the meaningful other, and liminality hinges as much on inclusion as on exclusion, just as disgrace is a part of grace as Lurie finally learns (Coetzee 2000:220).

The author's move to Australia, possibly metafictionally documented in Slow man, increases the suspicion that he has an affective agenda with his texts. Whilst Elizabeth Costello attempts to present the implied author's points of view through the mediation of the fictional character Costello, it is clear that Diary of a bad year divulges more intimate personal details regarding the author's interpretation of his responsibility towards effecting change in postcolonial society. Both Diary of a bad year and Elizabeth Costello include references to the concurrent postcolonial world and current political affairs that provide an anchor in spatial and temporal terms, emphasising the credibility of the texts as 'real'. Coetzee skilfully transfers responsibility for ethical choices from himself as transparent author to the reader. This process relieves him of the burden of accepting responsibility for the consequence of choices (in other words, the change) and also transfers this to the reader making the reader co-responsible for the text. It is typical of deconstructionist theory to deny the authority of the author as sole creator of the text (Baker 2005:46; Helgesson 2004:22). A decided advantage of this technique is that it creates a vehicle for the author to apply various distancing strategies to his text. The strategies enable Coetzee to open up the possibilities of interpretation and intention of his 
texts. Ultimately, the technique of distancing provides the perfect vehicle to emphasise the liminal hybridity and subversion of identity.

Fahraeus and Jonsson (2005:7) notes that the growing concern with forms of repression and usurpation proves the increased interest that textual ethics holds for writers such as Coetzee, who places himself in the eye of the storm - itself a liminal situation as it immediately conveys authorial involvement.

The contention is that the route followed by Coetzee via these texts culminates in an acceptance of the responsibility for exercising change and, therefore, of reaching liminal status. Liminality in itself is not a 'goal' but functions as a 'gateway' for ethical responsibility, illustrating the basis of change in postcolonial society. Coetzee provides the reader with as much authority to inscribe meaning in his fictional texts as might be acceptable to the reader. By giving up sole authority over the text, the writer gains ethical responsibility. Coetzee the writer prefers his protagonists, Costello, Rayment, Lurie, JC and Señor C, Barton, to tell their fascinating stories, ideally to an involved reader or co-writer, hoping, in the words of Szczurek (2009:44) that those who would listen, would become the wiser in terms of liminal adjustment.

If many of the critics consulted for this research regard the past as actively causing or generating the present and the future, Coetzee transcends the liminal in going one step further: he defines and 'creates' the past through the mediation of the present., therefore, no future without a past is subtly but significantly altered to no past without a future.

\section{Conclusion}

It is concluded that Coetzee's narratives are functional in constructing new identities, voicing the struggle of a variety of people who search for acceptance and the assertion of their identities. Coetzee not only introduces liminality to his reader but also encourages the reader to embrace the responsibility of accepting contemporary liminal changes, thereby influencing the postcolonial world's need to develop the potential offered by liminality. Coetzee promotes the acceptance of change. However, the act of reading becomes subversive as he never allows the reader to settle into the comfort of stability, thus, denying the reader any easy security.

\section{Acknowledgements Competing interests}

The authors declare that they have no financial or personal relationships which may have inappropriately influenced them in writing this article.

\section{Authors' contributions}

A.M.d.L. (North-West University) and M.J.W. (North-West University) were the promoters of the PhD of A.G. (NorthWest University), which led to the writing of this article.

\section{References}

Aguirre, M., 2006, 'Liminal terror: the poetics of gothic space', in A.M. Manzanas \& J. Benito (eds.), The dynamics of the threshold: Essays on liminal negotiations, pp. 13-38, Gateway Press, Madrid.

Arndt, S., 2006, 'Introduction: rereading (post)colonialism: Whiteness, wandering and writing', in S. Arndt \& M. Spitczok von Brisinski (eds.), Africa, Europe and (Post) colonialism: Racism, migration and diaspora in African literatures, pp. 13-82, colonialism: Racism, migration and diaspora in African literatures, pp. 13-82,
Eckhard Breitinger, Bayreuth University, Bayreuth. http://dx.doi.org/10.1016/ b978-044452186-6/50001-8

Arndt, S. \& Spitczok von Brisinski, M. (eds.), 2006, Africa, Europe and (post) colonialism: Racism, migration and diaspora in African literatures, Eckhard Breitinger, Bayreuth University, Bayreuth.

Baker, G., 2005, 'The limits of sympathy: J.M. Coetzee's evolving ethics of involvement', Ariel 36(1/2), 27-50.

Birks, C., 2007, “'Nothing is worse than what we can imagine": Secrecy and allegory in J.M. Coetzee's waiting for the barbarians and disgrace', Commonwealth Essays and Studies 30(1), 13-25.

Boehmer, E., 2005, Colonial and postcolonial literature: Migrating metaphors, University Press, Oxford.

Cattin, Y., 1999, 'Human beings cross frontiers', in F. Wilfred \& O. Beozzo (eds.), Frontier violations, p. 15, SCM Press, London.

Coetzee, J.M., 1986, Foe, Penguin, Harmondsworth.

Coetzee, J.M., 2000, Disgrace, Vintage Press (Random House), London.

Coetzee, J.M., 2003, Elizabeth costello, Secker \& Warburg, London.

Coetzee, J.M., 2006, Slow man, Vintage Press (Random House), London.

Coetzee, J.M., 2007, Diary of a bad year, Harvill Secker, London.

Derrida, J. [1976] 1986, Of grammatology, transl. G.C. Spivak, Johns Hopkins Press, Baltimore.

Dovey, T., 1988, The novels of J.M. Coetzee: Lacanian allegories, Donker, Craighall.

Du Plooy, H.J., 2006, 'Afstand en belewenis: liminale ruimtes en oorlewing in Niggie deur Ingrid Winterbach', Literator 27(1), 1-22. http://dx.doi.org/10.4102/lit.v27i1.176

Fahraeus, A. \& Jonsson, A. (eds.), 2005, Textual ethos studies - or locating ethics. Introduction, Rodopi, Amsterdam.

Gallagher, C., 2002, 'Undoing', in K. Newman, J. Clayton \& M. Hirsch (eds.), Time and the literary, pp. 11-30, Routledge, New York.

Graham, L., 2006, 'Textual transvestism. The female voices of J.M. Coetzee', in J. Poyner (ed.), J.M. Coetzee and the idea of the public intellectual, p. 225, Ohio University Press, Athens.

Head, D., 1997, J.M. Coetzee, University Press, Cambridge.

Helgesson, S., 2004. Writing in crisis. Ethics and history in Gordimer, Ndebele and Coetzee, University of KwaZulu-Natal Press, Scottsville.

Manzanas Calvo, A.M., 2006, 'At the gate: J.M. Coetzee's Elizabeth Costello and Thomas King's Truth and Bright Water', in J. Benito \& A.M. Manzanas Calvo (eds.), The dynamics of the threshold: Essays on liminal negotiations, pp. 89-104, Gateway Press, Madrid.

May, B., 2007, 'Reading Coetzee, eventually. Review of Attridge's “J.M.Coetzee and the ethics of reading: Literature in the event"', Contemporary Literature $48(4)$ 629-638. http://dx.doi.org/10.1353/cli.2008.0000

Ogden, B., 2010, 'The coming into being of literature: How J.M. Coetzee's diary of a bad year thinks through the novel', Novel: A Forum on Fiction 43(3), 466-482. http://dx.doi.org/10.1215/00295132-2010-025

Oxford Advanced Learner's Dictionary, 2007, 'Synecdoche', 7th edn., University Press, Oxford.

Palmer, A., 2004, Fictional minds, University of Nebraska Press, Lincoln \& London.

Samuelson, M., 2006, 'Fictional representations of rape in South African fiction of the transition', in S. Arndt \& M. Spitczok von Brisinski (eds.), Africa, Europe and (post) colonialism: Racism, migration and diaspora in African literatures, pp. 183-194, Eckhard Breitinger, Bayreuth University, Bayreuth.

Searle, J.R., 1992, The rediscovery of the mind, MIT Press, Cambridge.

Szczurek, K.M., 2009, 'Coetzee and Gordimer', in E. Boehmer, R. Eaglestone \& $\mathrm{K}$. Iddiols (eds.), J.M. Coetzee in context and theory, pp. 35-45, Continuum, London.

Talib, I.S., 2002, The language of postcolonial literatures: An introduction. Routledge, London.

Worthington, K.L., 1996, Selfas narrative: Subjectivity and community in contemporary fiction, Clarendon Press, Oxford. http://dx.doi.org/10.4324/9780203470183 